\title{
The effect of chemotherapy on status of estrogen receptors in primary tumors and lymph node metastases of human ductal breast cancer
}

\author{
MARIUSZ KODA, ANDRZEJ LENCZEWSKI, MARIOLA SULKOWSKA, LUIZA KANCZUGA-KODA, \\ ANDRZEJ WINCEWICZ, JAKUB TOMASZEWSKI and STANISLAW SULKOWSKI
}

Department of Pathomorphology, Collegium Pathologicum, Medical University of Bialystok, Poland

Received August 23,2006; Accepted November 3, 2006

\begin{abstract}
The aim of the study was the evaluation of ER $\alpha$ and ERß expression in primary tumors and lymph node metastases of breast cancer as well as the assessment of the influence of preoperative chemotherapy on these receptors with regard to changes in morphological appearance of primary tumors and their metastases. Immunohistochemical examinations were conducted on surgically removed ductal invasive breast cancers and their lymph node metastases of 135 patients. Seventy-one patients were spared preoperative chemotherapy which was administered to other 64 patients. Primary breast cancers with preoperative chemotherapy showed lower mean percentage of cells with a positive reaction to $\mathrm{ER} \alpha$ and $\mathrm{ER} \beta$ as compared to primary tumors without preoperative chemotherapy. There were positive correlations among primary tumors and lymph node metastases regardless of preoperative chemotherapy applied. On the other hand, ER $\alpha$ and ER $\beta$ expressions were negatively correlated in primary tumors without chemotherapy in contrast to primary tumors after chemotherapy. Furthermore, it was observed that preoperative chemotherapy was responsible for significantly less damage to lymph node metastases of breast cancer in comparison to primary tumors. In cases of such advanced damage of primary tumors that made determination of estrogen receptor expression impossible, their evaluation was performed on metastases to regional lymph nodes. Although preoperative chemotherapy did not severely impair estrogen receptor expression, presented changes of their distribution are a sufficient reason for simultaneous labeling of estrogen receptors in both primary tumors and metastases due to various sensitivity to chemotherapy of primary cancers in comparison with involved lymph nodes.
\end{abstract}

Correspondence to: Professor Stanislaw Sulkowski, Department of Pathomorphology, Medical University of Bialystok, Waszyngtona 13, 15-269 Bialystok, Poland

E-mail:sulek@zeus.amb.edu.pl

Key words: breast cancer, primary tumor, lymph node metastasis, preoperative chemotherapy, estrogen receptor $\alpha$, estrogen receptor $\beta$

\section{Introduction}

The relationship between estrogens and breast cancer was discovered $>100$ years ago when premenopausal bilateral ovariectomy induced remission of breast cancer (1). Estrogens play a key role in the development of breast cancer by stimulating, both in vivo and in vitro, neoplastic cell proliferation. Two estrogen receptors have been identified: alpha $(\mathrm{ER} \alpha)$ and beta $(\mathrm{ER} \beta)$. Each gene of both receptors are composed of eight exons and are situated at separate chromosomes, ER $\alpha$ at the long arm of chromosome 6 while ERß at the long arm of chromosome $14(2,3)$. The breast gland, uterus, bones, the cardio-vascular system, brain, and the urinary-reproductive system are the main targets of estrogen activity in the organism. ERß is the most predominant receptor in a certain region of the brain and in the cardiovascular system.

It is widely accepted that $\mathrm{ER} \alpha$ is a favorable prognostic factor in breast cancer. However, the importance of ERß receptor in breast cancer has not yet been fully explained. There was a relationship between ER $\beta$ expression and unfavorable prognostic factors including an increased expression of proliferation markers of Ki-67 and cyclin A $(4,5)$. An increased expression of mRNA ERß was also observed in breast cancer resistant to tamoxifen (6). However, in another study, ERß expression was related to favorable prognostic factors (7). Namely, ERß expression correlated with lack of lymph node metastases, higher stage of histological differentiation and longer survival time of patients $(7,8)$. Paruthiyil et al (9) showed that ER $\alpha$ intensified breast cancer cell proliferation while ERß inhibited it. ERß abolished the c-myc gene, cyclin D1 and cyclin A transcription, and intensified $\mathrm{p} 21^{\mathrm{Cip} 1}$ and $\mathrm{p} 27^{\mathrm{Kip} 1}$ expression, which led to cell cycle arrest in $\mathrm{G} 2$ phase. ER $\beta$ and $\mathrm{ER} \alpha$ fused to constitute heterodimers, which could lead to inhibition of ER $\alpha$ binding activity. ER $\alpha$ reacts with regions of responses to estrogens (ERE) localized in the range of various gene promoters, including those responsible for growth and proliferation. Therefore, ERß can inhibit neoplastic tumor proliferation and growth. Various isoforms of estrogen receptors have been described. ERßcx, which lacks ligand binding domain in C-terminal region, is one of such isoforms (10). Moreover, ERßcx is able to inhibit function of $\mathrm{ER} \alpha$ receptor by hetero- 
dimerization $(11,12)$. It was shown that there was far more $E R ß c x$ than the wild-type of ERß receptor in breast cancer (13). It was also suggested that ERßcx expression could be associated with tamoxifen resistance (14).

Preoperative chemotherapy (with or without hormonal therapy) is an integral part of management of patients with advanced breast cancer. Biological evaluation of parameters is usually performed in sections of primary tumor during routine histopathological diagnostics. It is assumed that the effect of chemo- or hormonal therapies on lymph node metastases should be similar to that on primary tumor. However, our and other studies showed differences of responses to systemic therapy between primary tumors and lymph node metastases. Dissimilarities can result from the heterogeneity of the expression of various biological factors between the cells of primary tumors and cancer cells in metastasis foci (15-17). The determination of cancer size or histological malignancy grade is in most cases almost impossible due to post-chemotherapy changes. The evaluation of estrogen receptor expression, which is routinely carried out before introduction of hormonal therapy, is also difficult.

The aim of the study was to evaluate ER $\alpha$ and ERß expression in primary breast cancer and its lymph node metastases. We also assessed the influence of preoperative chemotherapy on these receptors with regard to changes in morphological appearance of primary tumors and their metastases.

\section{Patients and methods}

Patients. The examinations were conducted in the group of 135 patients, aged 30-82 years (mean age 54.4). Preoperative chemotherapy was administered to 64 women while 71 of the patients underwent surgical operation without initial chemotherapy. The analysis was performed only in the cases of invasive ductal breast cancer in stages pT1 and pT2 as well as histological differentiation grades G2 and G3. Before the operation on patients with chemotherapy, Ansfield program (cyclophosphamide, prednisone, 5-fluorouracil, metotrexate, and vincristine) or CMF program (cyclophosphamide, metotrexate, 5-fluorouracil) were routinely applied as the algorithms of the first choice and FAC program (5-fluorouracil, doxorubicin, cyclophosphamide) as the alternative of the second choice. The effectiveness of preoperative chemotherapy on neoplastic process was not evaluated, thus, the subgroups of different types of treatment were not separated.

In 19 cases of patients who underwent chemotherapy (Fig. 1), we failed to visualize receptors due to severe damage to primary tumor cells. Therefore, further analyses, including statistical evaluation, were performed in the group of 45 women with invasive ductal breast cancer, in which immunohistochemical evaluation of examined markers was possible despite preoperative chemotherapy (Figs. 1 and 2).

In the group of cancers without preoperative chemotherapy $(n=71)$, the presence of regional lymph node metastases was diagnosed in 35 cases (49.3\%) (Fig. 2). Statistical analysis of cancers after preoperative chemotherapy $(n=45)$ revealed regional lymph node metastases in 30 patients $(66.7 \%)$.

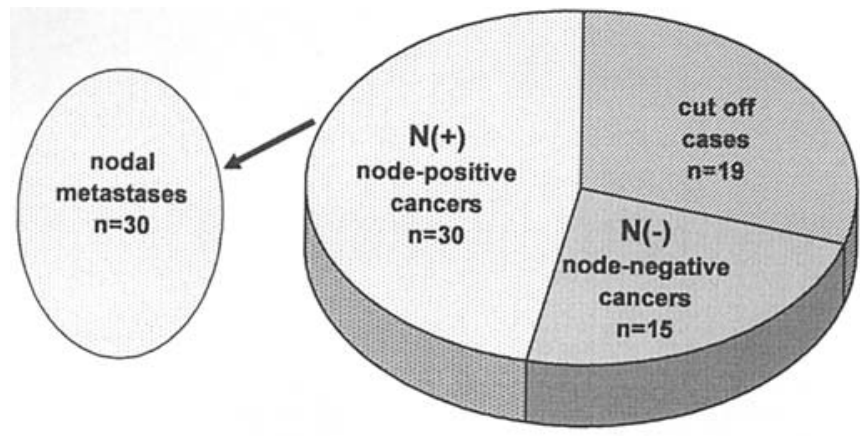

Figure 1. Groups of primary tumors and their nodal metastases that were treated with preoperative chemotherapy.

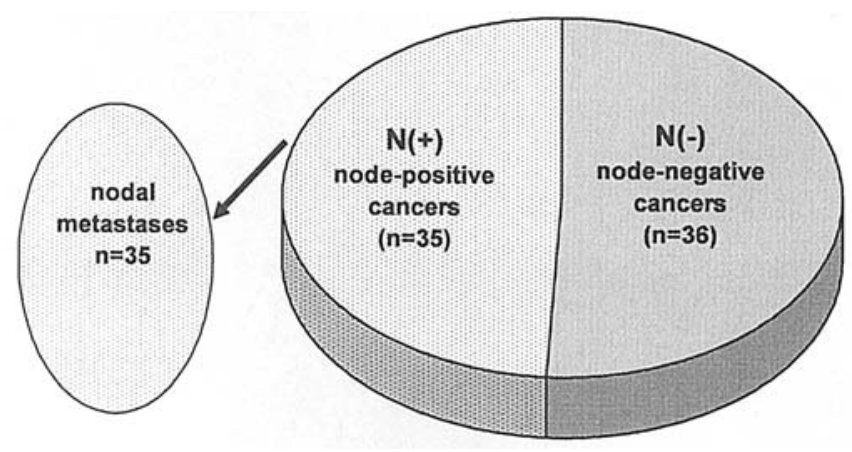

Figure 2. Groups of primary tumors and their nodal metastases without preoperative chemotherapy.

Methods. For immunohistochemical studies we selected two representative sections from each case of primary tumors and 1-4 involved lymph nodes with the largest metastatic foci. The quantity of chosen nodes depended on the number of nodes involved in each case. ER $\alpha$ was detected with a mouse monoclonal antibody (Ab) F-10 (Santa Cruz Biotechnology, USA) at dilution of 1:200. F-10 Ab recognizes epitope in the carboxy terminus of human ER $\alpha$ and does not cross-react with human ERß. ERß was detected with a rabbit polyclonal Ab H-150 (Santa Cruz Biotechnology) at dilution of 1:200. H-150 $\mathrm{Ab}$ recognizes amino acids $1-150$ in the amino terminus of human ERß. Archival ER-positive tissue specimens of breast cancer were used to select the optimal primary antibody dilutions. Estrogen receptor $\alpha$ and $\beta$ expressions were assessed as described previously $(15,16)$. The specificity of used antiERß antibodies were examined. Previously we suggested that this antibody probably recognized the ERßcx variant (15). Two independent pathologists evaluated immunostainings of studied proteins in 10 different tumor fields and the mean percentage of tumor cells with positive staining was scored. Negative controls were specimens that underwent the immunohistochemical procedure with omission of primary antibodies.

Statistical analysis. Spearman test was used to analyze the correlations between ER $\alpha$ and ERß. The differences in estrogen receptor expressions in patients with and without preoperative chemotherapy were evaluated using Mann-Whitney $\mathrm{U}$ test. Statistical significance was assumed at $\mathrm{p}<0.05$. 

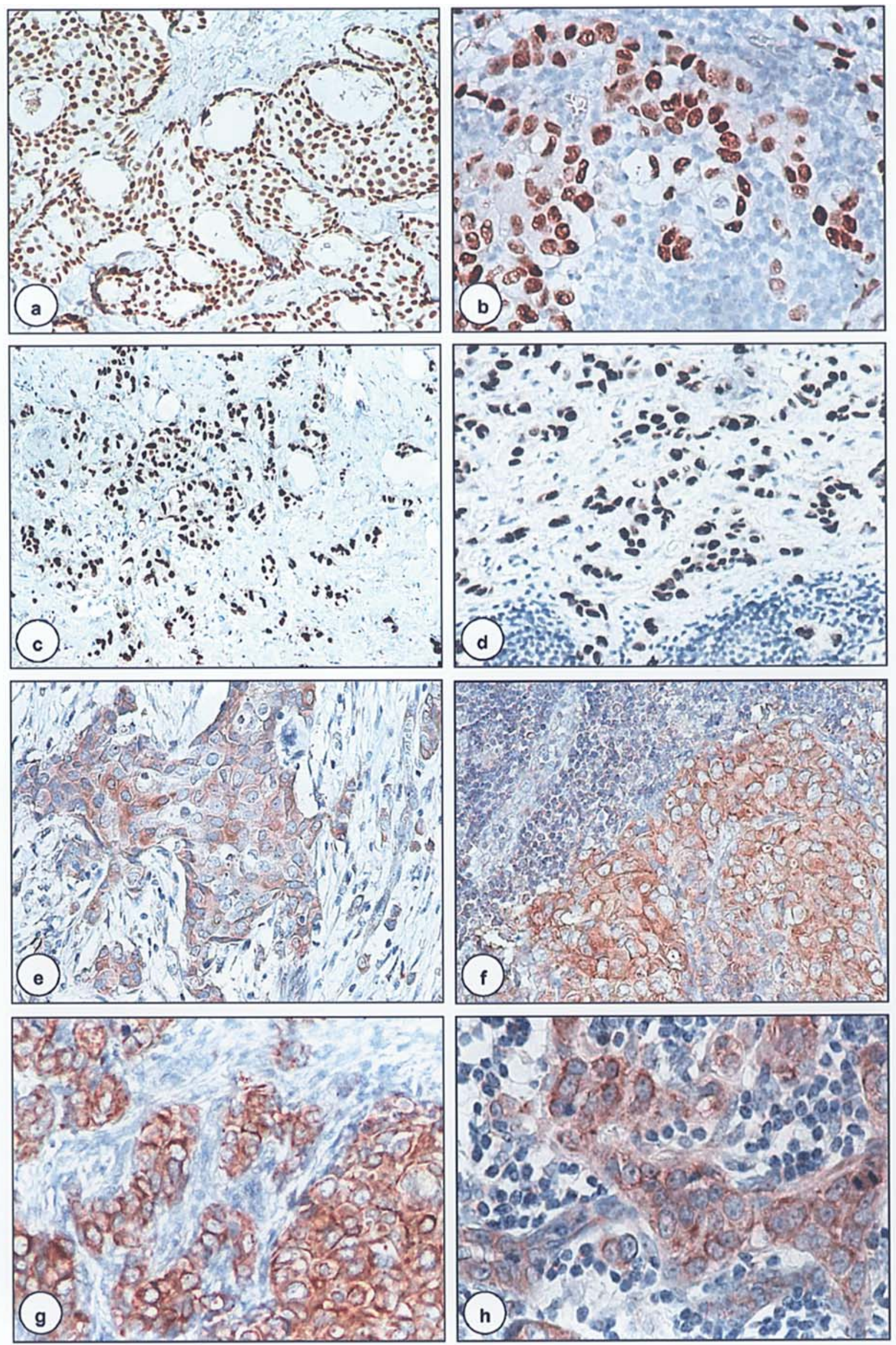

Figure 3. Immunohistochemical demonstration of ER $\alpha$ and ERß in breast cancer. Nuclear staining for ERß in primary tumor (a and c) and lymph node metastases (b and d) of breast cancer without ( $a$ and b) and after (c and d) preoperative chemotherapy. Perinuclear and cytoplasmatic staining for ERß was observed in primary tumor (e and g) and lymph node metastases ( $\mathrm{f}$ and $\mathrm{h}$ ) of breast cancer without (e and $\mathrm{f}$ ) and after ( $\mathrm{g}$ and $\mathrm{h}$ ) preoperative chemotherapy. Morphological changes associated with chemotherapy (c, d, g and h) as described in Results. 
Table I. Correlations between ER $\alpha$ and ERß in primary tumors without preoperative chemotherapy and nodal metastases.

\begin{tabular}{lcccr}
\hline \multicolumn{3}{c}{ Compared markers } & & \\
\cline { 1 - 2 } $\begin{array}{l}\text { Primary tumors } \\
\mathrm{n}=35\end{array}$ & $\begin{array}{c}\text { Lymph node } \\
\text { metastases, } \mathrm{n}=35\end{array}$ & $\mathrm{p}$ & $\mathrm{r}$ \\
\hline ER $\alpha$ & ER $\alpha$ & $\mathbf{p}<\mathbf{0 . 0 0 0 1}$ & 0.751 \\
ER $\alpha$ & ER $\beta$ & N.S. & -0.102 \\
ERß & ER $\alpha$ & & N.S. & -0.130 \\
ER $\beta$ & ER $\beta$ & $\mathbf{p}<\mathbf{0 . 0 3}$ & 0.391 \\
\hline
\end{tabular}

Bold, statistically significant; N.S., not significant.

\section{Results}

The evaluation of ERa expression in primary tumor and lymph node metastases of breast cancer without preoperative chemotherapy. A positive nuclear immunohistochemical reaction (Fig. 3a and b) to ER $\alpha$ was noted in $70.4 \%$ of primary tumor cases and $62.9 \%$ of regional lymph node metastases. In the negative controls with omission of primary antibodies, the specific reaction did not appear. Moreover, a weak cytoplasmatic anti-ER $\alpha$ reaction, absent in the negative controls, was sporadically observed in some neoplastic cells in primary tumors and lymph node metastases.

The evaluation of ERa expression in primary tumor and lymph node metastases of breast cancer after preoperative chemotherapy. Numerous morphological changes concerning the stroma and neoplastic cells occurred in sections of breast cancer after preoperative chemotherapy. The vacuolization of cytoplasm, hyperchromasia of nuclei, irregularity of nucleus membrane as well as fibrosis and stroma hyalinization were found. In 19 cases, which were not further analyzed statistically, only single neoplastic cells or their small clusters could be seen. However, neoplastic cell damage in lymph node metastases was slight in comparison with the primary tumors. The cytoplasm was vacuolized only to a small extent and some cases presented relatively intense fibrosis around the cancer fields. As the evaluation of ER $\alpha$ expression in 19 primary tumors was not possible, we decided to assess ER $\alpha$ expression in their metastases to lymph nodes. This occurred in 12 of 19 patients. We managed to visualize ER $\alpha$ in 8 cases of lymph metastases.

In the examined cases after preoperative chemotherapy, the immunoreactivity to $\mathrm{ER} \alpha$ was observed in $60 \%$ of primary tumors and $66.7 \%$ of lymph node metastases of breast cancer, which were analyzed statistically. There was no significant differences in the localization of reaction as compared to primary tumors and metastases from patients without preoperative chemotherapy (Fig. 3c and d). The negative controls did not show any specific reaction.

The evaluation of ERß expression in primary tumor and lymph node metastases of breast cancer without preoperative chemotherapy. Immunohistochemical reaction to ERß receptor
Table II. Correlations between ER $\alpha$ and ER $\beta$ in primary tumors with preoperative chemotherapy and nodal metastases.

\begin{tabular}{lccc}
\hline \multicolumn{2}{l}{ Compared markers post-chemotherapy } & & \\
\cline { 1 - 2 } $\begin{array}{l}\text { Primary tumors } \\
\mathrm{n}=30\end{array}$ & $\begin{array}{c}\text { Lymph node } \\
\text { metastases, } \mathrm{n}=30\end{array}$ & $\mathrm{p}$ & $\mathrm{r}$ \\
\hline $\mathrm{ER} \alpha$ & $\mathrm{ER} \alpha$ & $\mathbf{p}<\mathbf{0 . 0 0 0 1}$ & 0.722 \\
$\mathrm{ER} \alpha$ & $\mathrm{ER} \beta$ & N.S. & -0.120 \\
ERß & ER $\alpha$ & N.S. & -0.290 \\
ER $\beta$ & ER $\beta$ & $\mathbf{p}<\mathbf{0 . 0 2}$ & 0.458 \\
\hline
\end{tabular}

Bold, statistically significant; N.S., not significant.

was limited to neoplastic cell cytoplasm. Perinuclear reaction was observed in some cases (Fig. $3 \mathrm{e}$ and $\mathrm{f}$ ). In the negative controls with omission of primary antibody, there was no positive reaction to ERß. The expression of ERß receptor was observed in $85.9 \%$ of primary tumors and $83 \%$ of lymph node metastases.

The evaluation of ER $\beta$ expression in primary tumor and lymph node metastases of breast cancer after preoperative chemotherapy. The cytoplasmatic localization of immunohistochemical reaction to ERß was observed in cases after chemotherapy (Fig. $3 \mathrm{~g}$ and $\mathrm{h}$ ). The positive reaction was accomplished in $77.8 \%$ of primary tumors and $80 \%$ of lymph node metastases.

The analysis of ER $\alpha$ and ER $\beta$ relationships in breast cancer without preoperative chemotherapy. There was a positive correlation of $\mathrm{ER} \alpha-\mathrm{ER} \alpha$ and $\mathrm{ER} \beta$ - ER $\beta$ expression in primary tumors and lymph node metastases $(\mathrm{p}<0.0001, \mathrm{r}=0.751$; $\mathrm{p}<0.03, \mathrm{r}=0.391$, respectively) (Table I). However, the correlation between ER $\alpha$ and ERß expression in primary tumor and lymph node metastases was not observed (Table I). A negative correlation between $\mathrm{ER} \alpha$ and $\mathrm{ER} \beta$ expression was revealed in primary tumors in all patients $[\mathrm{N}(+)$ and $\mathrm{N}(-)$; $\mathrm{p}<0.006, \mathrm{r}=-0.327]$ and in patients without lymph node metastases [N(-); $<<0.04, \mathrm{r}=-0.355]$, and as a trend towards negative correlation in patients with metastases $[\mathrm{N}(+) ; \mathrm{p}=0.056$, $\mathrm{r}=-0.326]$ (Table III). We did not find a correlation between $\mathrm{ER} \alpha$ and ERß expression in metastases (Table IV).

The analysis of ER $\alpha$ and ERß relationships in breast cancer after preoperative chemotherapy. Similarly to the cases of cancer without preoperative chemotherapy, the positive correlations between ER $\alpha$ and ER $\alpha$ or ER $\beta$ and ER $\beta$ expressions were presented in primary tumors and lymph node metastases $(\mathrm{p}<0.0001, \mathrm{r}=0.722 ; \mathrm{p}<0.02, \mathrm{r}=0.458$, respectively) (Table II). We did not observe statistically significant relationships of ER $\alpha$ and ERß in primary tumors and lymph node metastases nor in primary tumors and metastases (Tables II-IV).

The comparison of ERa and ERß expression in breast cancers without and with preoperative chemotherapy. In order to 
Table III. Correlations between ER $\alpha$ and ERß in all primary tumors (PTs) $[\mathrm{N}(+)$ and $\mathrm{N}(-)]$, in node negative and node positive breast primary cancers in cases with or without preoperative chemotherapy.

\begin{tabular}{|c|c|c|c|c|}
\hline & \multicolumn{2}{|c|}{ Compared markers } & $\mathrm{p}$ & $\mathrm{r}$ \\
\hline \multicolumn{5}{|c|}{ PTs without chemotherapy, $n=71$} \\
\hline $\mathrm{N}(+)$ and $\mathrm{N}(-), \mathrm{n}=71$ & $\mathrm{ER} \alpha$ & $\mathrm{ER} ß$ & $\mathrm{p}<0.006$ & -0.327 \\
\hline $\mathrm{N}(-), \mathrm{n}=36$ & $\mathrm{ER} \alpha$ & $\mathrm{ER} ß$ & $\mathrm{p}<0.04$ & -0.355 \\
\hline $\mathrm{N}(+), \mathrm{n}=35$ & $\mathrm{ER} \alpha$ & $\mathrm{ER} ß$ & $p=0.056$ & -0.326 \\
\hline \multicolumn{5}{|c|}{ PTs after chemotherapy, $n=45$} \\
\hline $\mathrm{N}(+)$ and $\mathrm{N}(-), \mathrm{n}=45$ & $\mathrm{ER} \alpha$ & $\mathrm{ER} ß$ & N.S. & -0.015 \\
\hline$N(-), n=15$ & $\mathrm{ER} \alpha$ & $\mathrm{ER} ß$ & N.S. & -0.142 \\
\hline $\mathrm{N}(+), \mathrm{n}=30$ & $\mathrm{ER} \alpha$ & $\mathrm{ER} ß$ & N.S. & 0.038 \\
\hline
\end{tabular}

N.S., not significant.

Table IV. Correlation between ER $\alpha$ and ERß in lymph node metastases (LNM) of breast cancer in cases of applied or absent preoperative chemotherapy.

\begin{tabular}{lllll}
\hline & Compared markers & $\mathrm{p}$ & $\mathrm{r}$ \\
\hline LNM without chemotherapy, $\mathrm{n}=35$ & $\mathrm{ER} \alpha$ & $\mathrm{ER} ß$ & N.S. & -0.014 \\
LNM with chemotherapy, $\mathrm{n}=30$ & $\mathrm{ER} \alpha$ & $\mathrm{ER} ß$ & N.S. & -0.206 \\
\hline
\end{tabular}

N.S., not significant.

Table V. Comparison between ER $\alpha$ and ERß expressions in primary tumors (PTs) of the group that underwent preoperative chemotherapy and patients who did not receive prior chemotherapy (mean percentage of ER-positive cells $\pm \mathrm{SD})$.

\begin{tabular}{|c|c|c|c|}
\hline $\begin{array}{l}\text { Compared } \\
\text { markers }\end{array}$ & $\begin{array}{c}\text { PTs without } \\
\text { chemotherapy } \\
\text { (Mean } \pm \text { SD) } \\
n=71\end{array}$ & $\begin{array}{c}\text { PTs after } \\
\text { chemotherapy } \\
\text { (Mean } \pm \text { SD) } \\
n=45\end{array}$ & $\mathrm{p}$ \\
\hline $\mathrm{ER} \alpha$ & $45.9 \pm 33.3$ & $33.9 \pm 33.4$ & N.S. \\
\hline $\mathrm{ER} ß$ & $50.0 \pm 28.6$ & $44.2 \pm 28.4$ & N.S. \\
\hline
\end{tabular}

N.S., not significant.

determine a direct influence of preoperative chemotherapy on $\mathrm{ER} \alpha$ and ERß expression, the mean percentage of the cells with positive immunohistochemical reaction to these proteins in primary tumors and lymph node metastases without chemotherapy and with preoperative chemotherapy was compared (Tables V and VI). It should be stressed that the results concerned only the cases of cancer, which were influenced by chemotherapy, but the evaluation of analyzed markers was
Table VI. Comparison between ER $\alpha$ and ERß expressions in lymph node metastases (LNM) of the group that underwent preoperative chemotherapy and patients who did not receive prior chemotherapy (mean percentage of ER-positive cells $\pm \mathrm{SD})$

\begin{tabular}{|c|c|c|c|}
\hline $\begin{array}{l}\text { Compared } \\
\text { markers }\end{array}$ & $\begin{array}{c}\text { LNM without } \\
\text { chemotherapy } \\
\text { (Mean } \pm \text { SD) } \\
n=35\end{array}$ & $\begin{array}{c}\text { LNM after } \\
\text { chemotherapy } \\
(\text { Mean } \pm \text { SD) } \\
n=30\end{array}$ & $\mathrm{p}$ \\
\hline $\mathrm{ER} \alpha$ & $41.6 \pm 34.7$ & $44.5 \pm 35.8$ & N.S. \\
\hline $\mathrm{ERB}$ & $52.7 \pm 31.7$ & $53.7 \pm 30.3$ & N.S. \\
\hline
\end{tabular}

N.S., not significant.

possible. Primary tumors after preoperative chemotherapy showed lower mean percentage of cells with positive reaction to $\mathrm{ER} \alpha$ and $\mathrm{ER} \beta$ in comparison to primary tumors without preoperative chemotherapy. However, the influence was not statistically significant (Table V). Lymph node metastases, on the other hand, presented similar mean percentage of cells with positive reaction to ER $\alpha$ and ERß in both groups, with or without preoperative chemotherapy (Table VI). 


\section{Discussion}

Sections of breast cancer for immunohistochemical examination, including estrogen receptor occurrence, are usually collected from primary tumors. There are only some studies concerning the comparison of biological factor expression between primary tumors and regional lymph node metastases $(15,16,18-21)$. Women with locally advanced breast cancer undergo cytotoxic neoadjuvant therapy, which can cause marked histological changes in neoplastic tissues and thus makes it impossible to evaluate the status of estrogen receptor in primary tumor (22). In our study, 19 cases of breast cancer could not be evaluated for estrogen receptor expression in primary tumors, due to severity of cell damage from preoperative chemotherapy. On the basis of the results concerning the positive correlation between ER expression in primary tumors and lymph node metastases, we suggest that metastatic sections can be used as the material for the evaluation of estrogen receptors as prognostic markers in breast cancers. The utility of nodal samples was confirmed in the evaluation of ER $\alpha$ expressions, which were observed in 12 cases of lymph node metastases after preoperative chemotherapy. These metastases derived from the group of 19 patients who underwent chemotherapy and the evaluation of estrogen receptors was not possible due to primary tumor damage. Otherwise the results of such an evaluation in the primary tumor would not be credible. All 12 cases presented only slight morphological changes in metastases and 8 metastases were $\mathrm{ER} \alpha$ positive with typical nuclear localization of the reaction.

Preoperative chemotherapy is responsible for primary tumor reduction and enables surgical operation. However, its influence on estrogen receptor expression is relatively unknown. The evaluation of estrogen and progesterone receptor expression is a recognized management in breast cancer diagnostics and is treated as a predictive factor of the response to hormonal adjuvant therapy (23). Therefore, the knowledge of estrogen receptor status is essential in order to introduce adjuvant therapy with tamoxifen and aromatase inhibitors. However, our and other studies suggest that a possible influence of preoperative chemotherapy on ER expression should also be taken into account. Lee et al (24) showed that estrogen or progesterone receptor expression changes occurred in $61 \%$ of breast cancers after preoperative chemotherapy and in $5 \%$ of tumors the changes were so significant that ER-positive or ER-negative tumors after chemotherapy became ER-negative or ER-positive, respectively. The changes were not associated with the type of preoperative chemotherapy used. However, as our results point out, the evaluation of estrogen receptor expression in primary tumors after preoperative chemotherapy is not always possible while the evaluation of estrogen receptor expression in metastatic foci is possible and seems to be useful.

Breast cancer is a heterogeneous disease, in which various cellular clones are present in primary tumors, which have implications in cancer biology. The presence of estrogen receptors also has an impact on the behavior and development of breast cancer. It has not been determined whether estrogen receptor status has a role as a predictive factor of the response to chemotherapy. Lippman and Allegra (25) showed that patients with ER-negative tumors had a stronger response to chemotherapy as compared to those with ER-positive tumors. Taucher et al (26) suggested that preoperative chemotherapy could kill mainly ER-negative neoplastic cells. They also noted that the amount of ER-negative primary tumors increased significantly in patients with preoperative chemotherapy. Others (27-29) did not show any influence of preoperative chemotherapy on the expression of estrogen receptors.

Robertson (30) suggested that estrogen receptor expression is a stable phenotype of breast cancer. However, despite ER expression in neoplastic cells, the percentage of ER-positive (ER-negative) neoplastic cells can change in the course of the disease depending on the interaction between the host and the neoplasm. Jain et al (31) assessed estrogen receptor expression before chemotherapy and after the surgical operation in the same group of patients. They showed that in $17 \%$ of patients, ER expression after preoperative chemotherapy changed significantly and that the status of estrogen receptors was not a predictive factor of the response to chemotherapy. Unfortunately, we did not have the opportunity to compare the expression of estrogen receptors (and other markers) before and after chemotherapy in the same group of patients. We could only compare the expression in the groups of patients without and with preoperative chemotherapy. The results showed that ER expression in breast cancer, and particularly in primary tumors, is not a completely stable phenotype of neoplastic cells. It seems that the phenotype can, to a certain extent, be changed under the influence of administered preoperative chemotherapy. The assumption is supported by Morris et al (32) who reported certain cases of breast cancer, which completely lost or acquired ER-positivity as a consequence of preoperative chemotherapy.

Thus, if hormonal therapy is not planned before surgical operation, the evaluation of ER in primary tumors should be performed after the operation. Based on our findings it is useful and even indispensable to assess ER expressions in lymph node metastases of breast cancer, since in primary tumors evaluation of ER status can be hindered due to chemotherapy-induced cell loss and thus might not be representative of the hormonal sensitivity of total cancer tissue including metastases. This was seen in our previous studies, in which we examined the status of ER $\alpha$ and ERß in matched paired cases of primary tumors and lymph node metastases of breast cancer. We showed that a significant group of ER $\alpha$ - or ERß-positive primary tumors developed metastases with decreased (or absent) expression. On the other hand, we found ERs positive lymph node metastases, despite negative expression in primary tumors (15). This variation of ER status calls for its evaluation in lymph node metastases in each case of ductal breast cancer particularly when preoperative chemotherapy is involved.

\section{Acknowledgements}

This study was supported in parts by The Foundation for Polish Science (M.K.).

\section{References}

1. Clemons M and Goss P: Estrogen and the risk of breast cancer. N Engl J Med 344: 276-285, 2001. 
2. Enmark E, Pelto-Huikko M, Grandien K, Lagercrantz S, Lagercrantz J, Fried G, Nordenskjold M and Gustafsson JA: Human estrogen receptor $\beta$-gene structure, chromosomal localization, and expression pattern. J Clin Endocrinol Metab 82: 4258-4265, 1997.

3. Gosden JR, Middleton PG and Rout D: Localization of the human oestrogen receptor gene to chromosome $6 \mathrm{q} 24-\mathrm{q} 27$ by in situ hybridization. Cytogenet Cell Genet 43: 218-220, 1986.

4. Jensen EV, Cheng G, Palmieri C, Saji S, Van Noorden S, Makela S, Wahlstrom T, Warner M, Coombes RC and Gustafsson JA: Estrogen receptors and proliferation markers in primary and recurrent breast cancer. Proc Natl Acad Sci USA 98: 15197-15202, 2001.

5. Speirs V, Parkes AT, Kerin MJ, Walton DS, Carleton PJ, Fox JN and Atkin SL: Coexpression of estrogen receptor $\alpha$ and B: poor prognostic factors in human breast cancer? Cancer Res 59: 525-528, 1999.

6. Speirs V, Malone C, Walton DS, Kerin MJ and Atkin SL: Increased expression of estrogen receptor $B$ mRNA in tamoxifenresistant breast cancer patients. Cancer Res 59: 5421-5424, 1999.

7. Omoto $\mathrm{Y}$, Inoue $\mathrm{S}$, Ogawa S, Toyama T, Yamashita H, Muramatsu M, Kobayashi S and Iwase H: Clinical value of the wild-type estrogen receptor $B$ expression in breast cancer. Cancer Lett 163: 207-212, 2001.

8. Jarvinen TA, Pelto-Huikko M, Holli K and Isola J: Estrogen receptor $\beta$ is coexpressed with ER $\alpha$ and PR and associated with nodal status, grade, and proliferation rate in breast cancer. Am J Pathol 156: 29-35, 2000.

9. Paruthiyil S, Parmar H, Kerekatte V, Cunha GR, Firestone GL and Leitman DC: Estrogen receptor B inhibits human breast cancer cell proliferation and tumor formation by causing a G2 cell cycle arrest. Cancer Res 64: 423-428, 2004.

10. Ogawa S, Inoue S, Watanabe T, Orimo A, Hosoi T, Ouchi Y and Muramatsu M: Molecular cloning and characterization of human estrogen receptor Bcx: a potential inhibitor of estrogen action in human. Nucleic Acids Res 26: 3505-3512, 1998.

11. Ogawa S, Inoue S, Watanabe T, Hiroi H, Orimo A, Hosoi T, Ouchi Y and Muramatsu M: The complete primary structure of human estrogen receptor beta (hERß) and its heterodimerization with ERa in vivo and in vitro. Biochem Biophys Res Commun 243: 122-126, 1998.

12. Peng B, Lu B, Leygue E and Murphy LC: Putative functional characteristics of human estrogen receptor- $\beta$ isoforms. J Mol Endocrinol 30: 13-29, 2003.

13. Iwao K, Miyoshi Y, Egawa C, Ikeda N and Noguchi S: Quantitative analysis of estrogen receptor- $\beta$ mRNA and its variants in human breast cancers. Int J Cancer 88: 733-736, 2000.

14. Saji S, Omoto Y, Shimizu C, Warner M, Hayashi Y, Horiguchi S, Watanabe T, Hayashi S, Gustafsson JA and Toi M: Expression of estrogen receptor (ER) (beta)cx protein in ER(alpha)-positive breast cancer: specific correlation with progesterone receptor. Cancer Res 62: 4849-5483, 2002.

15. Koda M, Sulkowski S, Garofalo C, Kanczuga-Koda L, Sulkowska M and Surmacz E: Expression of the insulin-like growth factor-I receptor in primary breast cancer and lymph node metastases: correlations with estrogen receptors $\alpha$ and $B$. Horm Metab Res 35: 794-801, 2003.

16. Koda M, Sulkowski S, Kanczuga-Koda L, Surmacz E and Sulkowska M: Expression of ER $\alpha, E R ß$ and Ki-67 in primary tumors and lymph node metastases in breast cancer. Oncol Rep 11: 753-759, 2004.

17. Koda M, Sulkowska M, Kanczuga-Koda L and Sulkowski S: Expression of insulin receptor substrate 1 in primary breast cancer and lymph node metastases: J Clin Pathol 58: 645-649, 2005.
18. Koda M, Jarzabek K, Kanczuga-Koda L, Przystupa W, Tomaszewski J, Sulkowska M, Wolczynski S and Sulkowski S: Comparative studies of Ki-67 expression between the primary tumor and breast cancer metastases to regional lymph nodes. Ginekol Pol 74: 754-760, 2003.

19. Lacroix H, Iglehart JD, Skinner MA and Kraus MH: Overexpression of erbB-2 or EGF receptor proteins present in early stage mammary carcinoma is detected simultaneously in matched primary tumors and regional metastases. Oncogene 4: 145-151, 1989.

20. Mori T, Morimoto T, Komaki K and Monden Y: Comparison of estrogen receptor and epidermal growth factor receptor content of primary and involved nodes in human breast cancer. Cancer 68: 532-537, 1991.

21. Neskovic-Konstantinovic ZB, Nikolic-Vukosavljevic DB, Brankovic-Magic MV, Mitrovic LB and Spuzic I: Content of epidermal growth factor receptor in metastatic breast cancer: its role in endocrine sensitivity prediction. Neoplasma 47: 107-113, 2000.

22. Aktepe F, Kapucuoglu N and Pak I: The effects of chemotherapy on breast cancer tissue in locally advanced breast cancer. Histopathology 29: 63-67, 1996.

23. Harvey JM, Clark GM, Osborne CK and Allred DC: Estrogen receptor status by immunohistochemistry is superior to the ligandbinding assay for predicting response to adjuvant endocrine therapy in breast cancer. J Clin Oncol 17: 1474-1481, 1999.

24. Lee SH, Chung MA, Quddus MR, Steinhoff MM and Cady B: The effect of neoadjuvant chemotherapy on estrogen and progesterone receptor expression and hormone receptor status in breast cancer. Am J Surg 186: 348-350, 2003.

25. Lippman ME and Allegra JC: Quantitative estrogen receptor analyses: the response to endocrine and cytotoxic chemotherapy in human breast cancer and the disease-free interval. Cancer 46: 2829-2834, 1980

26. Taucher S, Rudas M, Gnant M, Thomanek K, Dubsky P, Roka S, Bachleitner T, Kandioler D, Wenzel C, Steger G, Mittlbock M and Jakesz R: Sequential steroid hormone receptor measurements in primary breast cancer with and without intervening primary chemotherapy. Endocr Relat Cancer 10: 91-98, 2003.

27. Bottini A, Berruti A, Bersiga A, Brunelli A, Brizzi MP, Marco BD, Cirillo F, Bolsi G, Bertoli G, Alquati P and Dogliotti L: Effect of neoadjuvant chemotherapy on Ki-67 labelling index, c-erbB-2 expression and steroid hormone receptor status in human breast tumours. Anticancer Res 16: 3105-3110, 1996.

28. Hawkins RA, Tesdale AL, Anderson ED, Levack PA, Chetty U and Forrest AP: Does the oestrogen receptor concentration of a breast cancer change during systemic therapy? Br J Cancer 61: 877-880, 1990.

29. Schneider J, Lucas R, Sanchez J, Ruibal A, Tejerina A and Martin M: Modulation of molecular marker expression by induction chemotherapy in locally advanced breast cancer: correlation with the response to therapy and the expression of MDR1 and LRP. Anticancer Res 20: 4373-4377, 2000.

30. Robertson JF: Oestrogen receptor: a stable phenotype in breast cancer. Br J Cancer 73: 5-12, 1996.

31. Jain V, Landry M and Levine EA: The stability of estrogen and progesterone receptors in patients receiving preoperative chemotherapy for locally advanced breast carcinoma. Am Surg 62: 162-165, 1996.

32. Morris DM, Edwards J and Gelder F: Hormonal receptors in locally advanced breast cancer: change with response to neoadjuvant chemotherapy? J Surg Oncol 46: 156-158, 1991. 